\title{
コンクリート充填角形鋼管短柱の安定した塑性変形を発揮する圧縮耐力 STABILIZED COMPRESSIVE STRENGTH UNDER PLASTIC DEFORMATION OF CONCRETE FILLED SQUARE STEEL TUBE SHORT COLUMNS
}

\author{
山本貴正 ${ }^{*}, 川 口 \quad$ 淳**, 山田和夫*** \\ Takamasa YAMAMOTO, Jun KAWAGUCHI and Kazuo YAMADA
}

\begin{abstract}
The authors estimated the deteriorated compressive strength of concrete filled square steel tube (square CFT) short columns after the maximum strength attained, which is defined as the stabilized compressive strength $\left(N_{\text {stab }}\right)$. Next, the stabilized bending moment $\left(M_{\text {stab }}\right)$ of square CFT columns were calculated by use of $N_{\text {stab }}$. Compression tests of high strength square CFT short columns using steel-fibered concrete (FR-CFT) were also carried out, in order to improve the compressive ductility. As results, the following has been found: i) $N_{\text {stab }}$ decreases as the yield stress increases. ii) calculated $M_{\text {stab }}$ shows good agreement with the experimental results. iii) axial compressive ductility of square FR-CFT short column is higher than square CFT with concrete without steel fibered.
\end{abstract}

Keywords : Compressive Strength, Yield Stress, Axial Compressive Strength, Bending Moment, Previous Experimental Data, Fiber Reinforcement 圧縮強度, 降伏応力度, 軸圧縮耐力, 曲げモーメント, 既往の実験データ, 繊維補強

1. はじめに

\section{1 本研究の背景 $\cdot$ 目的}

高層建築物の構造形式として, コンクリート充填鋼管（以下， CFT）柱構造が多く採用されている。しかし，その耐震設計における 崩壊機構は, 主として梁降伏型であり, CFT 柱特有の高勒性を活かし ていない注 1)。そこで, CFT 柱の高勒性を活かすため, CFT 柱構造の 崩壊機構を従来の梁降伏型に加え, 一部柱降伏を許容することが提 案されている例えば，2）。また，CFT 柱の断面形状は主として，円形お よび角形の 2 種類あり，角形 CFT 柱構造は円形と比較して，柱梁接 合部の継手・仕口における施工性が優れることなどから，施工実績 が高い。よって, 今後, 角形 CFT 柱の勒性は, さらに重要視される ことが予測される。

角形 CFT 短柱の勒性は, AIJ-CFT 指針 : 2008 $8^{3)}$ ( 以下，CFT 指針）の 鋼管およびコンクリートの応力度 - ひずみ度関係モデルを用いれば, 各種因子の軸圧縮耐力 - 軸圧縮変位関係および曲げモーメントー曲 率関係を比較して評価することができる。しかし，その勒性評価に は, 多大な労力が必要で, かつ勒性を数值的に評価することが難しい。 また，これらの関係から，角形 CFT 柱の耐力劣化を含む水平力と部材角 の関係を解析的に導出するには, 鋼管の局部座屈およびコンクリートの破
壊による耐力低下が生じる破壊領域および除荷される非破壊領域の長さ 範囲の設定に難がある ${ }^{4)}$ 。

単調軸圧縮を受ける CF T 短柱の軸圧縮特性は, CFT 柱の耐力・靭 性の指標となる。角形では, 耐力低下後にある程度変形が進むと, Fig. 1 に示寸ように, 耐力低下後に最小の軸圧縮耐力（以下, 最小圧 縮耐力）が認められ, その直後, 軸圧縮耐力が一定に安定すること が数多くの研究で確認されている。このことから, 角形 CFT 短柱の 最大耐力到達後にある程度耐力が低下し, 鋼管の局部座屈およびコン クリートの破壊による脆性的な破壞が生じない状態（以下，安定した 塑性変形）になる圧縮耐力 [ 以下，安定圧縮耐力：stabilized compres-

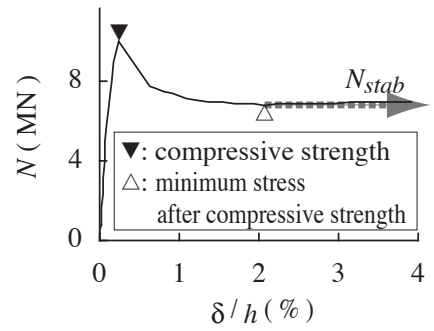

\begin{tabular}{c}
$B=400 \mathrm{~mm}, \quad B / t=44.0$ \\
$\sigma_{y}=346 \mathrm{~N} / \mathrm{mm}^{2}, \quad \sigma_{B}=33.9 \mathrm{~N} / \mathrm{mm}^{2}$ \\
\hline$B \quad:$ width of steel tube \\
$t \quad:$ wall thickness of steel tube \\
$\sigma_{y} \quad:$ yield stress of test piece \\
$\quad$ cut from steel tube \\
$\sigma_{B} \quad:$ compressive strength \\
of concrete standard test piece \\
$h \quad:$ specimen height \\
$N_{\text {stab }}:$ stablilized compressive strength
\end{tabular}

Fig.1 An example of axial compressive load $(N)$ - axial compressive deformation $(\delta)$ relationship of square CFT short column ${ }^{5}$ )

\footnotetext{
* 国立豊田工業高等専門学校建築学科 准教授・博士 (工学)

** 三重大学大学院工学研究科 准教授. 博士 (工学)

$* * *$ 愛知工業大学工学部建築学科 教授 $\cdot$ 工博
}

Assoc. Prof., Dept. of Architecture, Toyota National College of Technology, Dr. Eng. Assoc. Prof., Graduate School of Engineering, Mie University, Dr. Eng.

Prof., Dept. of Architecture, Faculty of Engineering, Aichi Institute of Technology, Dr. Eng. 
sive strength $\left.\left(N_{\text {stab }}\right)\right]$ を定量的に把握することは, 角形 CFT 柱の勒性 の評価につながると考えられている ${ }^{6)}$ 。なお, 安定圧縮耐力時の鋼 管とコンクリートの応力度も一定になると仮定すると, 曲げを受け る柱の曲げモーメントも耐力低下後に一定に安定することになる。

以上より，本論では，まず角形 CFT 柱の勒性の評価につながると 考えられる安定圧縮耐力を, 既往の実験データをもとに検討してい る。また曲げを受ける柱の最大耐力到達後、ある程度耐力が低下寸ると, 圧縮耐力と同様に, 曲げモーメントが一定に安定することが確認されてい るため ${ }^{7)}$, この安定した塑性変形を発揮する曲げモーメント [以下, 安 定曲げモーメント : stabilized bending moment $\left.\left(M_{\text {stab }}\right)\right]$ の算定に安定圧 縮耐力が適用できるかを, 既往の研究成果を活用して検討している。 さらに，高強度材料を用いた角形 CFT 柱の勒性の改善を図ることを 目的として, 従来から多くの研究成果が蓄積されている高勒性鋼繊 維補強コンクリートに着目し, 鋼繊維補強を施した角形 CFT 短柱の 圧縮勒性についても，実験的に検討している。なお，ここでは，単調 軸圧縮力および等曲げモーメントを受ける柱を CFT 短柱, 軸力と水平力を 受ける柱を CFT 柱と定義する。

\section{2 本研究に関連する既往の研究成果}

\section{（1）単調軸圧縮を受ける角形 CFT 短柱}

CF T 短柱の最大圧縮耐力に及ぼす鋼管とコンクリートの相互作用 (以下，相乗効果）を検討する際，その比較対象として，次式に示す 鋼管とコンクリートの断面耐力の累加（以下，CFT 断面耐力）が用い られる。

$$
N_{0}=A_{s} \cdot \sigma_{y}+\psi \cdot A_{c} \cdot \sigma_{B}
$$

ここに, $A_{s}, A_{c}$ : 鋼管およびコンクリートの原断面積, $\psi$ : コンクリー 卜の寸法効果による補正係数

角形 CFT 短柱の最大圧縮耐力は, CFT 指針の幅厚比制限值内であれ ば，式（1）の寸法効果を加味した CFT 断面耐力で，表すことができ る ${ }^{5,8)}$ 。よって, 最大圧縮耐力に及ぼす相乗効果はないと言われてい る。なお, これはコンクリートの形状効果による耐力低下と, 相乗 効果による耐力上昇が相殺するためであると筆者らは考えている ${ }^{5)}$ 。

角形 CF T 短柱の鋼管およびコンクリートの応力度 - ひずみ度関係 は, コンファインドコンクリート, 鋼管短柱などの実験結果をもと に構成している中原ら ${ }^{9)}$ の計算モデルで精度よく表すことができる。 なお，このモデルは，耐力低下後に相乗効果が考慮されている。

\section{（2）一定軸力下の等曲げを受ける角形 CFT 短柱}

角形 CFT 短柱の一定軸力下における等曲げモーメントー曲率関係 は, 単調および繰返し載荷ともに, 中原らの応力度-ひずみ度関係 モデル 9）をもとに提案された中原らの計算モデル ${ }^{7,10)}$ で精度よく表 すことができる。なお，このモデルは，鋼管の曲げ引張側を 2 軸引 張応力状態としている。

\section{2. 検討対象とする角形 CFT 短柱試験体}

角形 CFT 短柱の安定圧縮耐力を, 次の試験体を対象として検討寸る。 i）鋼管とコンクリートを同時に圧縮載荷している。i i ) 鋼管内面に 突起がない。iii）コンクリートに膨張性混和剤が混入されていない。 i v ) コンクリートに空洞および鋼材が含まれていない。v）溶接四面 組立鋼管を使用していない。vi）CFT 指針の幅厚比制限值を超える鋼 管を使用していない。

上記の条件 i i ) は，通常の鋼管を用いた CFT 短柱と比較して耐力 が上昇することがある，ｉｉｉ）は，鋼管内と強度試験用供試体の型枠 内で養生したコンクリートの圧縮強度が異なることがある,v）は， 鋼管の角溶接の溶込みの影響で, 局部座屈発生後の耐力低下が大き くなりやすいことがある ${ }^{11)}$, vi）は, 最大圧縮耐力が，本研究で， 安定圧縮耐力の高低の基準とする式（1）のCFT 断面耐力に達しな いためである。なお，ここでは簡単に，鋼管の隅角部の曲率半径お よび溶接シーム面を無視し板厚を断面一様と寸る。また，隅角部お よびシーム面の加工硬化は, 各文献において不明であるため無視し, 降伏応力度を断面一様とする。

\section{3. 角形 CFT 短柱の安定圧縮耐力}

前掲 Fig.1 に示すように, 角形 CFT 短柱の単調軸圧縮試験において, 最小圧縮耐力を発揮した直後, 軸圧縮耐力が一定に安定することが 数多くの研究で確認されている。そこで, 最小圧縮耐力を安定圧縮 耐力とする。なお，最小圧縮耐力が認められる試験体を標本とした 注 2), 5, 12-25)。その標本の因子範囲を Table 1 に示寸注 3)。

Fig.2 に, CFT 断面耐力に対寸る安定圧縮耐力（以下，安定圧縮耐 力比) と CFT 断面耐力に対寸る鋼管断面耐力 (以下, 鋼管断面耐力比) の関係に及ぼす鋼管の降伏応力度の影響を示す。図中の実線, 破線 および一点鎖線は，それぞれ降伏応力度 294-428，440-554 および 618-834N/ $\mathrm{mm}^{2}$ の近似直線である。なお，CFT 断面耐力は，式（1）よ り補正係数を 1.0 として計算している。以下, 断りがない限り, 補 正係数は 1.0 とする。

同図より，鋼管断面耐力比が小さい，および鋼管の強度レベルが

Table 1 Properties of specimens ${ }^{5,12-25)}$ for calibration ( compressive tests of square CFT short columns )

\begin{tabular}{c|c|c|c}
\hline factor & \multicolumn{3}{|c}{ yield stress $\sigma_{y}$ range } \\
\hline$\sigma_{y}\left(\mathrm{~N} / \mathrm{mm}^{2}\right)$ & $294-428$ & $440-554$ & $618-834$ \\
\hline$B(\mathrm{~mm})$ & $100-400$ & $151-250$ & $120-200$ \\
\hline$B / t$ & $17-49$ & $17-34$ & $19-31$ \\
\hline$\sigma_{B}\left(\mathrm{~N} / \mathrm{mm}^{2}\right)$ & $18-119$ & $25-213$ & $25-119$ \\
\hline$N_{s y} / N_{0}(\psi=1.0)$ & $0.26-0.78$ & $0.30-0.85$ & $0.48-0.84$ \\
\hline number of specimens & 38 & 9 & 5 \\
\hline$N_{s y}:$ cross sectional strength of steel tube $\left(=A_{s} \cdot \sigma_{y}\right)$
\end{tabular}

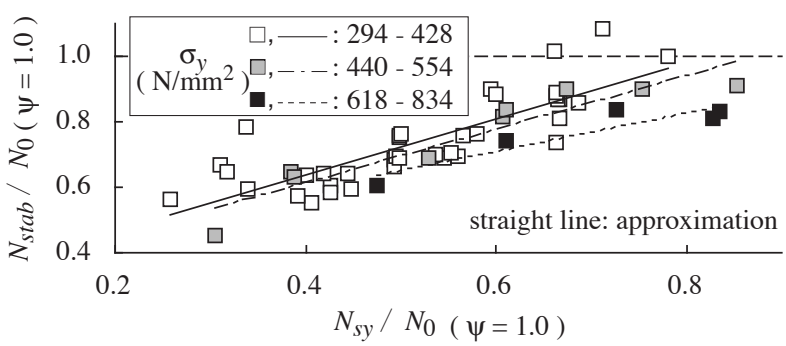

Fig.2 Relations between $N_{s t a b} / N_{0}$ and $N_{s y} / N_{0}$

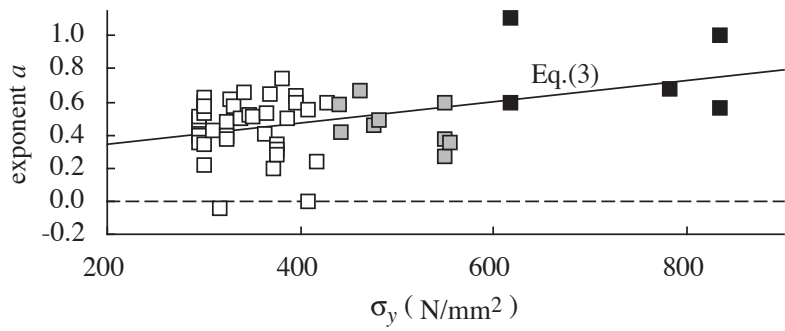

Fig.3 Relations between exponent $a$ of Eq.(2) and yield stress 


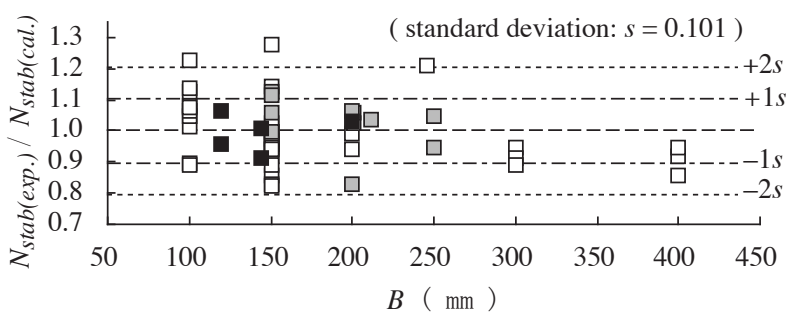

(a) Relations with width of steel tube

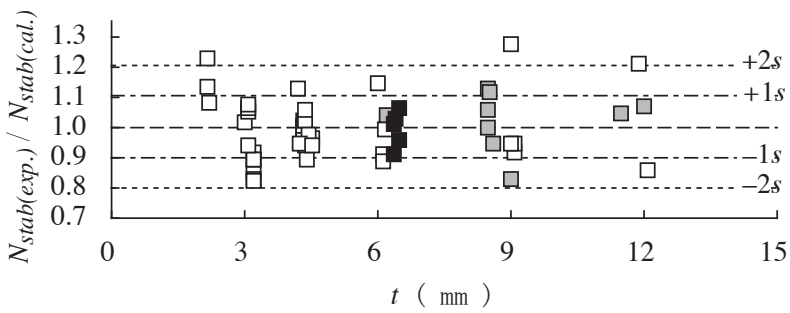

( b ) Relations with width of steel tube

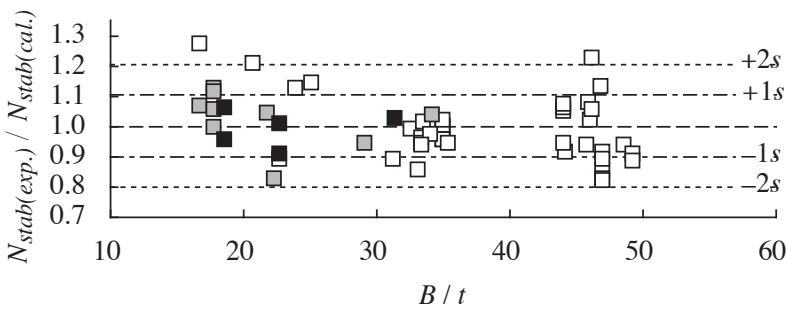

(c) Relations with compressive strength of concrete test piece

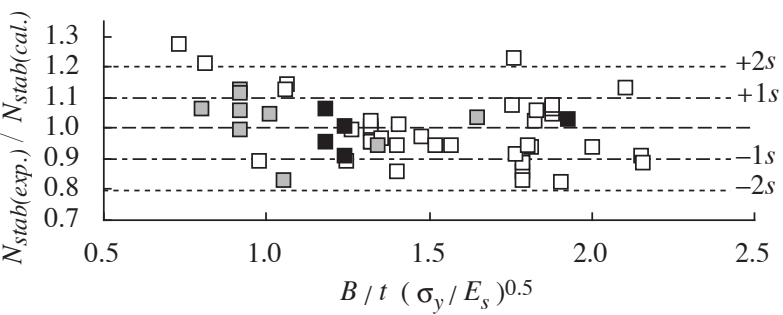

(d) Relations with generalized width-thickness ratio

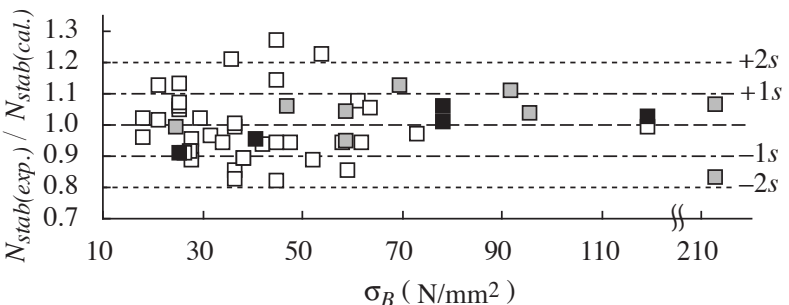

(e ) Relations with compressive strength of concrete test piece

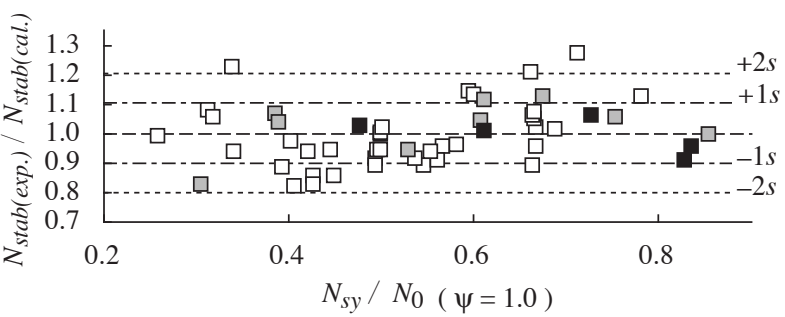

( f ) Relations with $N_{s y} / N_{0}$

Fig.4 Comparisons between experimental stabilized compressive strength $\left(N_{\text {stab( } \exp .)}\right)$ and calculated ones $\left(N_{\text {stab( }(c a l .)}\right)$

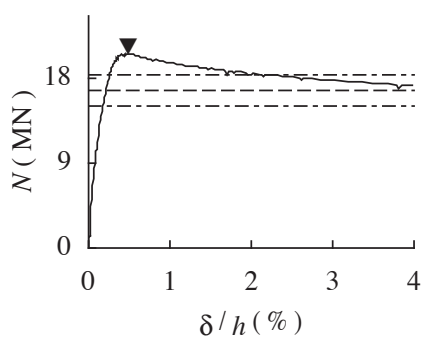

$B=400 \mathrm{~mm}, B / t=17.9, N_{s y} / N_{0}=0.64$ $\sigma_{y}=412 \mathrm{~N} / \mathrm{mm}^{2}, \sigma_{B}=58.9 \mathrm{~N} / \mathrm{mm}^{2}$
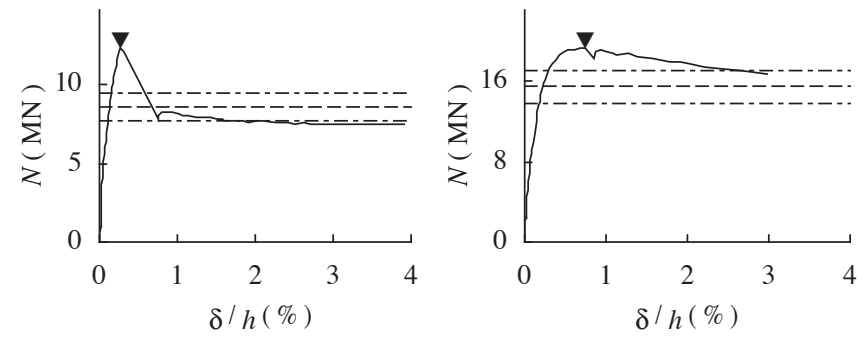

$B=400 \mathrm{~mm}, \quad B / t=44.0, \quad N_{s y} / N_{0}=0.3$
$\sigma_{y}=346 \mathrm{~N} / \mathrm{mm}^{2}, \sigma_{B}=58.9 \mathrm{~N} / \mathrm{mm}^{2}$

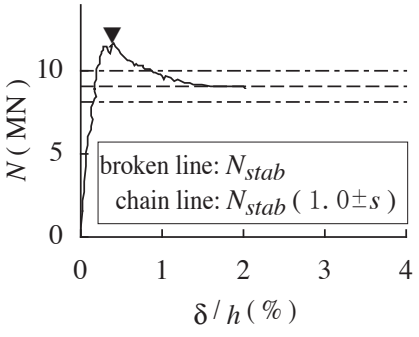

$B=400 \mathrm{~mm}, \quad B / t=33.1, \quad N_{s y} / N_{0}=0.59$ $\sigma_{y}=346 \mathrm{~N} / \mathrm{mm}^{2}, \sigma_{B}=33.9 \mathrm{~N} / \mathrm{mm}^{2}$

Fig.5 Comparisons between experimental $N-\delta$ relationships ${ }^{5)}$ and calculated stabilized compressive strength

高いほど安定圧縮耐力比が小さいことがわかる。後者については, 鋼管断面耐力比が同等の場合, 降伏応力度が高いほど一般化幅厚比 $\left[B / t\left(\sigma_{y} / E_{S}\right)^{0.5}\right]$ が高くなり, 鋼管が負担する軸圧縮耐力が局部座屈の 影響で低下寸るためと考えられる注 4 )。そこで，安定圧縮耐力比と鋼 管断面耐力比の関係を，次式で評価することを試みた。

$$
N_{\text {stab }} / N_{0}=\left(N_{\text {sy }} / N_{0}\right)^{a}
$$

式 ( 2) の $N_{\text {stab }}$ に実験值を代入し, 逆算して算出した指数 $a$ と降 伏応力度の関係を Fig.3 に示す。各印は, Fig.2 と同様であり, 実線 は次式に示寸直線近似である。

$$
a=132 \sigma_{y} / E_{s}+0.22
$$

ここに, $E_{S}:$ 鋼管のヤング係数 $\left(=206 \mathrm{kN} / \mathrm{mm}^{2}\right)$

なお，式（2），（3）の安定圧縮耐力の計算値に対寸る実験值の標準 偏差 $s$ は 0.101 である。

Figs.4(a)-(f)に，式（2），（3）の安定圧縮耐力の計算値に対する 実験值と鋼管断面幅, 鋼管板厚, 鋼管幅厚比, 鋼管の一般化幅厚比,
コンクリート標準供試体（断面直径 $100 \mathrm{~mm}$, 高さ $200 \mathrm{~mm}$ ) の圧縮強度 および鋼管断面耐力比の関係をそれぞれ示す。各印は, Fig.2 と同様 であり，一点鎖線および点線は，それぞれ $1 s$ および $2 s$ を表している。 また, Fig.5に，最小圧縮耐力が認められないため前掲 Table 1 の標本に 含まれていない鋼管断面幅が $400 \mathrm{~mm}$ の試験体の軸圧縮耐力と試験体高さ に対する軸圧縮変位の関係の実験值と, 安定圧縮耐力の計算值を併 せて示す。破線は，安定圧縮耐力の計算值を，一点鎖線は，標準偏 差土 $1 s$ (前掲 Fig.4 参照) を加えた安定圧縮耐力の計算值をそれぞれ 表している。

Figs.4,5より, 安定圧縮耐力の計算值に対する実験值に及ぼす各種 因子の影響は，ほとんどないことが認められる。よって，安定圧縮 耐力は，式 (2)，（3）で表すことができ，i）鋼管断面耐力比が同等の 場合, 降伏応力度が高いほど, 安定圧縮耐力比が小さくなる, ii）降 伏応力度が同等の場合，幅厚比の大小および圧縮強度の高低は，同 一の安定圧縮耐力比 - 鋼管断面耐力比関係上を推移寸る, i i i ) 安定 
圧縮耐力の計算において, 無視している鋼管の断面・力学性状に及 ぼす隅角部およびシーム面の影響は小さい, と考えられる。

式 ( 2), (3) の安定圧縮耐力比の計算值は, 例えば, 鋼管幅厚 比 30 , 鋼管の降伏応力度 $300 \mathrm{~N} / \mathrm{mm}^{2}$ およびコンクリートの圧縮強度 $30 \mathrm{~N} / \mathrm{mm}^{2}$ (鋼管断面力比 0.60 ) では, 0.81 であり, この圧縮強度を $120 \mathrm{~N} / \mathrm{mm}^{2}$ (鋼管断面力比 0.27 ) にすると 0.58 となる。さらに降伏応 力度を $800 \mathrm{~N} / \mathrm{mm}^{2}$ (鋼管断面力比 0.50$)$ にしても, 安定圧縮耐力比は 0.60 である。よって, コンクリートの高強度化は, 圧縮勒性が低く なる, また鋼管の高強度化は, 圧縮勒性の改善を期待できないと考 えられる。

\section{4. 角形 CFT 柱の安定曲げモーメント}

\section{1 安定曲げモーメントの計算モデル}

CFT 指針および中原ら ${ }^{10)}$ の終局曲げモーメントの計算モデルを参 考にした Fig.6 に示寸応力分布を用いて, 一定軸力 $\left(N_{\text {const }}\right)$ を受ける 安定曲げモーメント $\left(M_{\text {stab }}\right)$ を, 次式で算出する。

$$
\begin{aligned}
M_{s t a b} & =M_{s}+M_{c} \\
M_{s} & =\left[(S+\beta)(B-\mathrm{t}) B \cdot t / 2+t \cdot x_{n}(S+\beta)\left(B_{c}-x_{n}\right)\right] \sigma_{y} \\
M_{c} & =r \cdot \sigma_{B} \cdot B_{c} \cdot x_{n}\left(D_{c}-x_{n}\right) / 2
\end{aligned}
$$

式 (4) の変数 $x_{n}$ は, 一定軸力を用いて次式より算出する。

$$
\begin{aligned}
N_{\text {const }} & =N_{s}+N_{c} \\
N_{s} & =\left[(S-\beta) B \cdot t+2 t \cdot x_{n}(S+\beta)-2 t \cdot B_{c} \cdot \beta\right] \sigma_{y} \\
N_{c} & =r \cdot \sigma_{B} \cdot B_{c} \cdot x_{n}
\end{aligned}
$$

鋼管の引張応力度は, 二軸応力状態を考慮し, 降伏応力度の $\beta$ 倍 とするが, この安定曲げモーメント時の定数 $\beta$ については研究の現 状では不明な点が多いため, ここでは簡単に中原ら ${ }^{7,10)}$ の計算モデ ルを参考に 1.1 とする。また, 定数 $S, r$ は, 安定圧縮耐力時の鋼管 とコンクリートの応力度が一定值に収束すると仮定して, さらに, 簡単に, ヤング係数に比例し弾性回復するモデルで, 計算する主 5)。 コンクリートのヤング係数は, 密度が各文献において不明であるた め, 圧縮強度のみをパラメータとしている次式の雨宮式 ${ }^{26)}$ とした。

$$
E_{c}=\left(3.57 \sigma_{B}^{0.5}+5.7\right) \times 10^{3} \text {, 単位は } \mathrm{N} / \mathrm{mm}^{2}
$$

以上の計算モデルで安定曲げモーメントを算出する。ただし, 高い 軸力比および高い鋼管の降伏応力度では注 ${ }^{6)}$, 变数 $x_{n}$ が鋼管ウェブ $(B-2 t)$ 内にある全ての場合において, 引張合力が圧縮合力より高く, 軸力が釣り 合わないため, 安定曲げモーメントの解が得られない。これは, 計算モデ ルが，前掲の Fig. 6 に示寸ように，鋼管の引張断面の全領域を降伏応力度 と仮定していることが原因である。よって, 高い軸力比および高い降伏応 力度では, 定数 $\beta$ を小さくする必要がある。しかし, 定数 $\beta$ と各種要因 との関係については不明であり, 今後の検討課題である。なお，終局曲げ モーメント時では, 高い軸力比および高い鋼管の降伏応力度において, 鋼 管の引張縁のひずみ度が降伏ひずみに達していない実験結果が得られてい る27)。

\section{2 安定曲げモーメントの実験值と計算值の比較}

一定軸力と水平力を受ける CFT 柱の曲げモーメントと部材角の関 係は, 耐力低下後において, その漸増繰返し載荷曲線の累積曲線と 単調載荷曲線の対応が良いことが認められている ${ }^{28)}$ 。また, 連名者 $5^{29,30)}$ は, 角形 CFT 柱のある一定の変位振幅下における漸増繰返 し曲げ試験を実施し, 各サイクルの最大水平力, 最大変位振幅時の

\begin{tabular}{|c|c|c|c|c|c|c|c|}
\hline & specimens & $\begin{array}{cccc}B & \underline{B} & \sigma_{y} & \sigma_{B} \\
(\mathrm{~mm}) & t & \left(\mathrm{~N} / \mathrm{mm}^{2}\right) \\
\end{array}$ & $\begin{array}{l}\underline{L} \\
B \\
\end{array}$ & $\frac{N_{\text {const }}}{N_{0}}$ & $\frac{N_{s y}}{N_{0}}$ & $\frac{N_{\text {stah }}}{N_{0}}$ & $\begin{array}{l}\text { loading } \\
\text { condition }\end{array}$ \\
\hline \multirow{12}{*}{ 1) } & SR4-A-4-C & 21036.032339 .2 & 6.0 & 0.38 & 0.50 & 0.74 & \multirow{12}{*}{ tie rod type } \\
\hline & SR4-A-9-C & 21036.032388 .2 & 6.0 & 0.38 & 0.31 & 0.61 & \\
\hline & SR4-C-4-C & 21046.732639 .2 & 6.0 & 0.37 & 0.43 & 0.70 & \\
\hline & SR4-C-9-C & 20946.432688 .2 & 6.0 & 0.38 & 0.25 & 0.55 & \\
\hline & SR6-A-4-C & 21123.958839 .3 & 6.0 & 0.35 & 0.74 & 0.84 & \\
\hline & SR6-A-9-C & 21123.958888 .3 & 6.0 & 0.35 & 0.56 & 0.71 & \\
\hline & SR6-C-4-C & 21135.560939 .3 & 6.0 & 0.34 & 0.66 & 0.78 & \\
\hline & SR6-C-9-C & 21035.360993 .7 & 6.0 & 0.36 & 0.45 & 0.61 & \\
\hline & SR8-A-4-C & 17818.883742 .3 & 6.0 & 0.40 & 0.83 & 0.87 & \\
\hline & SR8-A-9-C & 17918.983794 .5 & 6.0 & 0.40 & 0.69 & 0.76 & \\
\hline & SR8-C-4-C & 18027.080542 .3 & 6.0 & 0.41 & 0.76 & 0.82 & \\
\hline & SR8-C-9-C & 18027.080594 .5 & 6.0 & 0.40 & 0.59 & 0.68 & \\
\hline \multirow{2}{*}{ 30) } & $31 \mathrm{C} 1510$ & 10033.432422 .6 & 10.5 & 0.15 & 0.65 & 0.83 & \multirow{4}{*}{ cantilever } \\
\hline & $31 \mathrm{C} 3010$ & 10033.432422 .6 & 10.5 & 0.30 & 0.65 & 0.83 & \\
\hline 31) & $\mathrm{C} 253$ & 15025.050532 .8 & 5.0 & 0.30 & 0.74 & 0.85 & \\
\hline 33) & CBC-32-80-20 & $030534.3600 \quad 110$ & 4.9 & 0.20 & 0.41 & 0.58 & \\
\hline \multirow{4}{*}{ 32) } & R33-03-60 & 10033.440368 .5 & 6.0 & 0.30 & 0.44 & 0.68 & \multirow{4}{*}{$\begin{array}{r}\text { kenken-type } \\
\text { (Wakabayashi } \\
\text {-type) }\end{array}$} \\
\hline & R33-04-60 & 10033.440368 .5 & 6.0 & 0.40 & 0.44 & 0.68 & \\
\hline & R44-02-60 & 10044.338461 .5 & 6.0 & 0.20 & 0.38 & 0.64 & \\
\hline & R44-04-60 & 10044.338461 .5 & 6.0 & 0.40 & 0.38 & 0.64 & \\
\hline
\end{tabular}
水平力, および 1 サイクルの履歴曲線の面積が, サイクル数の増大

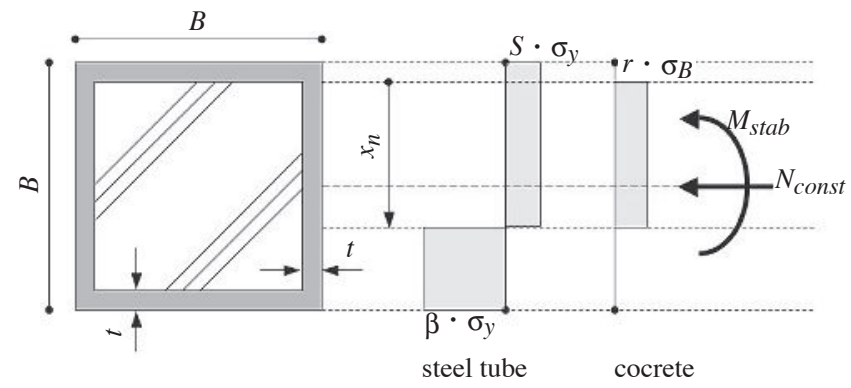

$N_{\text {const }}:$ applied axial load, $x_{n}:$ variable $(\leqq B-2 t), S, \beta, r:$ constant

Fig.6 Stress distribution of steel tube and concrete in stabilized bending moment

Table 2 Square CFT column specimens tested under cyclic bending or shear bending ( previous experimental data )

$\bar{L}:$ test length of bending or shear bending tests, $N_{0}$ : calculated by Eq.(1) with $\psi=1.0$

に伴い一定值に収束する実験結果を得ている。

以上より，角形 CFT 柱の漸増繰返し曲げおよび曲げせん断試験の 複数回の繰返し履歴における材端曲げモーメントの実験值と前述 4. 1 節の計算モデルで算出した安定曲げモーメントを比較し, 計算 モデルの妥当性を検討する。実験值は，既往の実験データ 1,30-33）を 用い, Table 2 に対象としている角形CFT柱試験体の因子が示してある。 なお, 対象としている試験体の条件は, 前述 2 章の CFT 短柱と同様 である。

文献 30-33) では実験結果の耐力を水平力で整理している。そこで, この水平力の実験值と, 安定曲げモーメントの計算值を用いて次式 で算出する安定曲げモーメント時の水平力 $H_{s t a b}$ ( 以下, 安定水平力) を比較する。

$$
\text { 曲げ試験 : } H_{\text {stab }}=\left(M_{s t a b}-N_{\text {const }} \cdot R \cdot L\right) / L
$$

曲げせん断試験 : $H_{\text {stab }}=\left(2 M_{\text {stab }}-N_{\text {const }} \cdot R \cdot L\right) / L$

ここに, $R$ : 部材角, $L:$ 試験部分の柱長さ

Figs.7(a),(b) に, それぞれ P-delta モーメントを含めた材端曲げモー メントおよび水平力と部材角の関係の実験最終サイクル 1,30-33）と 安定曲げモーメントおよび安定水平力の計算值を併せて示す。縦軸 は，それぞれ最大曲げモーメントおよび最大水平力の実験值で無次 


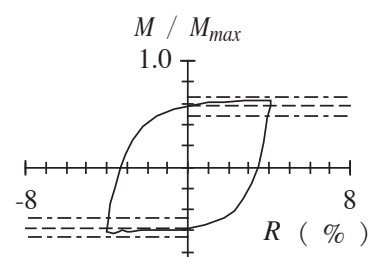

$-1.0 \perp \quad$ SR4A4C
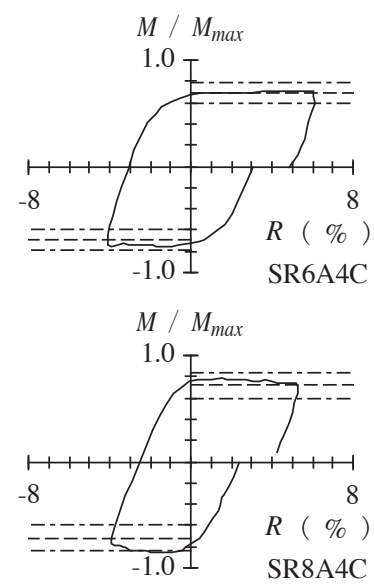

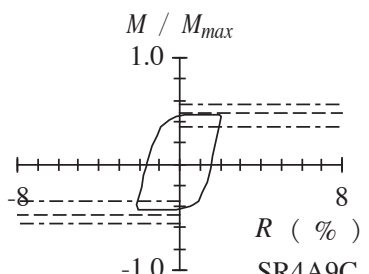

$-1.0-\mathrm{SR} 4 \mathrm{~A} 9 \mathrm{C}$
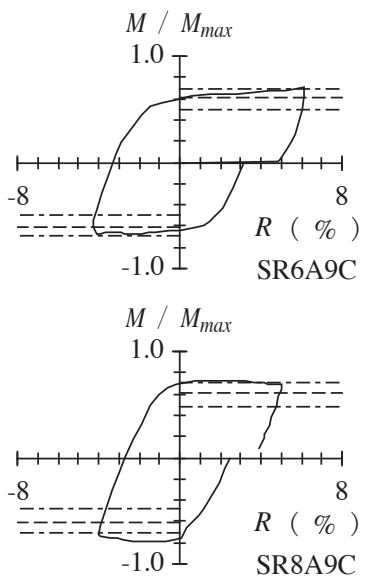

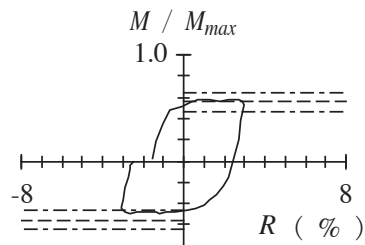

$-1.0 \perp$

SR4C4C

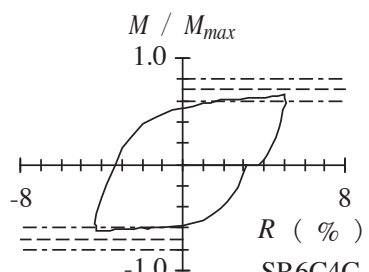

SR6C4C

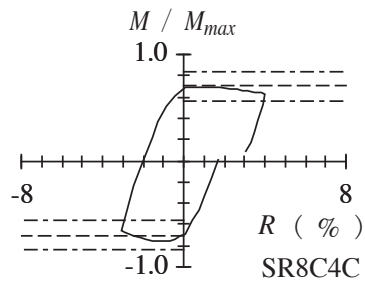

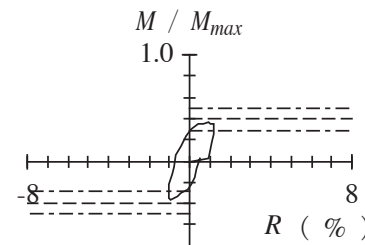

$-1.01$

SR4C9C

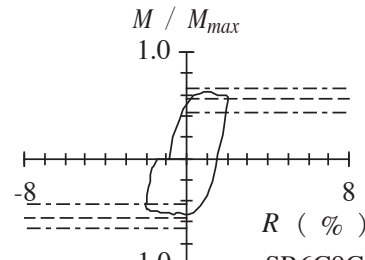

-1.0 工

SR6C9C

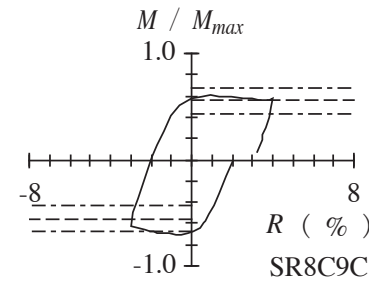

broken line and chain line: calculated stabilized bending moment using $N_{s t a b}$ and $N_{\text {stab }}(1.0 \pm s), M_{\max }$ : experimental maximum bending moment

( a ) Comparisons between experimental final cycle of bending moment $(M)$ - chord rotation angle $(R)$ relationship ${ }^{1)}$ and calculated stabilized bending moment
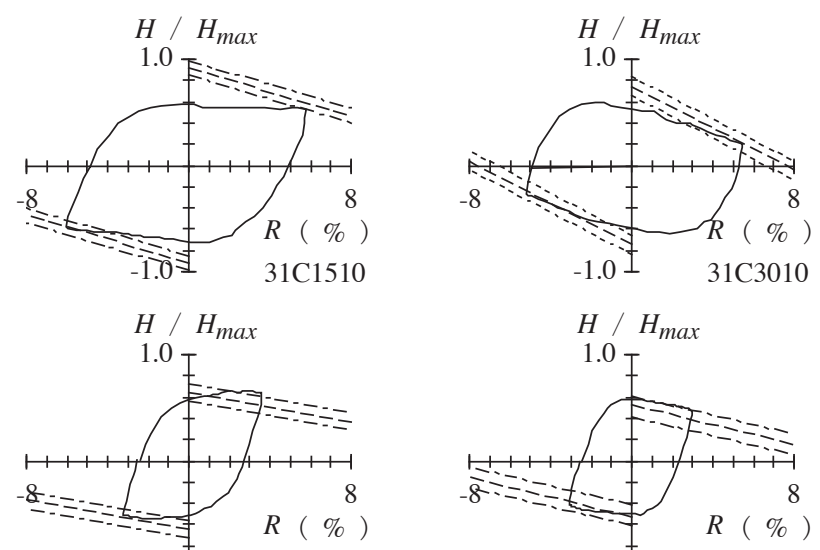

$-1.0 \perp$ R33-03-60

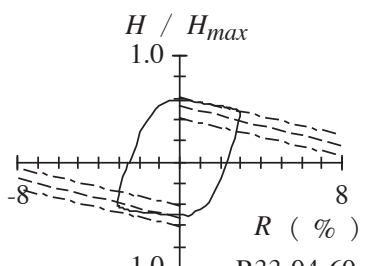

R33-04-60
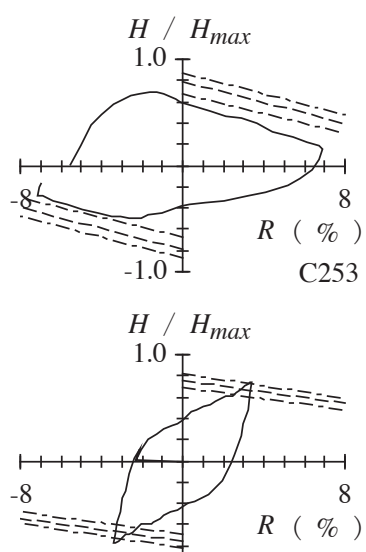

-1.0 I R44-02-60

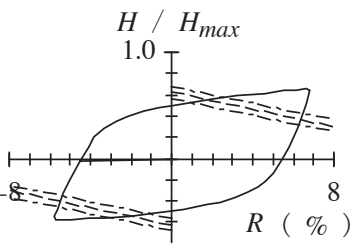

$-1.0 \perp_{\mathrm{CBC}-32-80-20}$

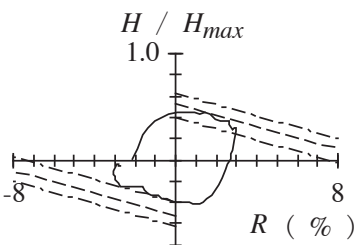

-1.0 R44-04-60

broken line and chain line: calculated stabilized horizontal load using $N_{s t a b}$ and $N_{\text {stab }}(1.0 \pm s), H_{\text {max }}$ : experimental maximum horizontal load

( b ) Comparisons between experimental final cycle of horizontal load $(H)$ - chord rotation angle $(R)$ relationship ${ }^{30-33)}$ and calculated stabilized horizontal load

Fig.7 Comparisons between experimental final cycle of $M-R$ or $H-R$ relationship and calculated stabilized bending moment and horizontal load

元化してある。破線は, 安定曲げモーメントおよび水平力の計算值 を, 一点鎖線は, 標準偏差 (前掲 Fig. 4 参照) を加えた安定圧縮耐力 $\left[N_{s t a b}(1.0 \pm s)\right]$ を用いて算出した安定曲げモーメントおよび安定水 平力の計算值をそれぞれ表している。

同図 (a),(b) より，試験体 31C1510，CBC-32-80-20 および R44-02-60 の 3 体を除き, 安定曲げモーメントおよび安定水平力の計算值は, 実験值付近に存在し, かつ実験值と平行であり, その傾向を表して いることがわかる。なお，試験体 31C1510，CBC-32-80-20および R44-02-60 については，実験值が他の試験体と異なり，最大振幅時ま で, 水平力の低下が認められない。これらは軸力比が 0.2 以下で小 さく, 優れたエネルギー吸収能力を有しており ${ }^{34)}$, 実験值が, 安定 水平力に到達していない, ようは, 実験において安定曲げモーメン 卜および安定水平力に到達する状態にないため, 計算值は, その傾
向と一致しないと考えられる。

\section{5. 鋼纎維補強を施した角形 CFT 短柱の圧縮靭性}

前述 3 章より, 角形 CFT 短柱の圧縮勒性は, 高強度コンクリート を使用寸るとすると低くなる，また高張力鋼を用いても，ほとんど 改善が改善されないと推測される。そこで，角形 CFT 柱の勒性の改 善を図ることを目的として, 従来から多くの研究成果が蓄積されて いる高勒性鋼繊維補強コンクリートに着目し，鋼繊維補強を施した 角形 CFT 短柱（以下，繊維補強角形 CFT 短柱）の圧縮勒性の改善効 果を, 実験的に検討した。

\section{1 実験概要}

\section{（1）実験因子範囲}

実験の因子およびその範囲として，繊維補強の有無を取り上げた。 
なお, 参考のため, 無補強の角形 $\mathrm{CFT}$ 短柱 (以下, 無補強角形 CFT 短柱) と同等の CFT 断面耐力を有する円形 CFT 短柱 ( 以下, 無補強円形 CFT 短柱）の実験も併せて実施した。

\section{（2）使用材料・試験体作製}

鋼管は，一般構造用角形鋼管 STKR400 および一般構造用炭素鋼 管STK500 を用いた。寸法は公称でそれぞれ 100x100x2.3mm，および 114. $3 \times 1.8 \mathrm{~mm}$ である。

Table 3 にコンクリートの調合表を示す。繊維混入率は外割体積で $4 \%$ である。セメントは普通ポルトランドセメント（密度 $: 3.15 \mathrm{~g} /$ $\left(\mathrm{m}^{3}\right.$ ), 細骨材は天竜川産の川砂 (表乾密度 $: 2.64 \mathrm{~g} / \mathrm{cm}^{3}$, 吸水率: $0.82 \%$ ), 混和剤は高性能 $\mathrm{AE}$ 減水剤 (主成分：ポリカルボン酸系コポリマー) を使用した。鋼繊維は, 立体波形の普通鋼繊維（長さ：40mm, 直径 : $0.8 \mathrm{~mm}$, 波長: $10 \mathrm{~mm}$, 振幅: $1.5 \mathrm{~mm}$, 製造方法:カットワイヤー) である。 なお,コンクリート標準供試体用の型枠は内径 $100 \mathrm{~mm}$, 内高 $200 \mathrm{~mm}$ の 鋼製型枠を使用した。また，コンクリート標準供試体の養生は，CFT 短柱試験体と同一条件にするため, その強度試験日まで実験室内に て封緘養生とした。

コンクリートの混練には, 容量 $60 l$ の二軸強制練ミキサを使用した。 ミキサの軸回転数は $4 \mathrm{r} / \mathrm{min}$ である。コンクリートの鋼管への充填工法 は, 縦方向打設の落とし込みとし, 3 層詰めで, 各層を突き棒で 25 回 突き，その後，プラスチックハンマーで，突き棒によりできた穴がな くなるまで鋼管側面を軽く吒いた。試験体の高さに対する断面寸法の 比は 3 である。なお, 鋼繊維有無のコンクリートは, それぞれ異な るバッチで作製した。また, 䋊維補強コンクリートを標準供試体用 の型枠および鋼管に充填する作業において, 通常のハンドスコップ
と併用して，ハンドフォークを使用した。

\section{（3）圧縮試験方法}

実施した CFT 短柱の圧縮試験の概要を Fig.8 に示す。圧縮試験では, 相対する 2 台の変位計で上下の支圧板間の軸方向変位を測定した。 荷重は鋼管とコンクリートを同時に単調載荷する形式とし，平均軸 方向ひずみ度が $6 \%$ になるまで加えることを原則とした。なお，上下 端ともに材端条件は，固定である。圧縮試験は，材齢 4 週後に実施 した。標準供試体の圧縮試験は, 圧縮応力度の増大を毎秒 $0.6 \mathrm{~N} / \mathrm{mm}^{2}$ の自動制御で実施した。

\section{2 実験結果·考察}

Tables 4(a),(b)に，鋼管からの採取片の引張試験結果，およびコン クリート標準供試体の圧縮試験結果をそれぞれ示す。また, Table 5 に, CFT 短柱の圧縮試験結果一覧が示してある。

Fig.9 に, 角形 CFT 短柱の軸圧縮而力と試験体高さに対する軸圧縮 変位の関係に及ぼす繊維補強の影響を示す。縦軸は, 最大軸圧縮而 力で無次元化してある。

同図より, 繊維補強角形 CFT 短柱の最大圧縮耐力到達後の耐力低 下勾配は，無補強と比較して緩やかであり，鋼繊維補強による角形 CFT 短柱の圧縮勒性の改善が認められる。なお, 最大圧縮耐力に対す る安定圧縮強度は, 繊維補強の有・無によりそれぞれ 0.69 および 0.55

Table 3 Mix proportions of concrete

\begin{tabular}{cccccccc}
\hline$W / C$ & Air & $S P$ & $W$ & $C$ & $S_{a}$ & $A D / C$ fiber volume fraction \\
\cline { 4 - 6 }$(\%)$ & $(\%)$ & $(\mathrm{mm})$ & \multicolumn{2}{c}{$\left(\mathrm{kg} / \mathrm{m}^{3}\right)$} & $(\%)$ & $(\% . \mathrm{vol})$ \\
\hline 23.7 & $4.5 \pm 1.5$ & $12 \pm 2.5$ & 243 & 1023 & 1023 & 1.75 & $4.0^{*}$ \\
\hline
\end{tabular}

Air: air content, $S P$ : slump, $W$ : water, $C$ : cement, $S_{a}$ : fine aggregate $A D$ : additive $\left(\mathrm{kg} / \mathrm{m}^{3}\right),{ }^{*}$ outer percentage

Table 4 Material properties

( a ) Tensile test results of test piece cut from steel tube

\begin{tabular}{ccccc}
\hline \multirow{2}{*}{ steel type } & $t$ & $\sigma_{y}$ & \multirow{2}{*}{ yield ratio breaking elongation } \\
& $(\mathrm{mm})$ & $\left(\mathrm{N} / \mathrm{mm}^{2}\right)$ & & $(\%)$ \\
\hline STKR400 & 2.11 & 353 & 0.752 & 31.0 \\
\hline STK500 & 1.78 & $410(0.2 \%$ off-set $)$ & 0.789 & 16.5 \\
\hline
\end{tabular}

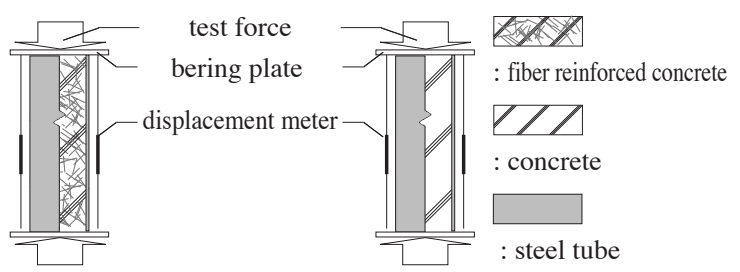

fiber reinforced CFT short columns CFT short columns ( un-reinforcement )

fig.8 Compression Test methods of CFT short columns
( b ) Compressive test results of concrete standard test piece

\begin{tabular}{|c|c|c|c|c|c|}
\hline \multirow{2}{*}{ steel fiber } & \multirow{2}{*}{$\begin{array}{l}\text { number of } \\
\text { specimens }\end{array}$} & \multicolumn{2}{|c|}{$\sigma_{B}$} & \multicolumn{2}{|c|}{ dencity } \\
\hline & & $\begin{array}{l}\text { mean value } \\
\left(\mathrm{N} / \mathrm{mm}^{2}\right)\end{array}$ & $\begin{array}{l}\text { C.V. } \\
(\%)\end{array}$ & $\begin{array}{c}\text { mean value } \\
\left(\mathrm{g} / \mathrm{cm}^{3}\right)\end{array}$ & $\begin{array}{l}\text { C.V. } \\
(\%)\end{array}$ \\
\hline un-reinforced & 5 & 80.9 & 3.28 & 2.28 & 0.255 \\
\hline reinforcement & 5 & 95.1 & 3.04 & 2.63 & 0.582 \\
\hline
\end{tabular}

C.V.: coefficient of variation

Table 5 Compressive test results of CFT short columns

\begin{tabular}{|c|c|c|c|c|c|c|}
\hline specimens & $\begin{array}{l}B(D) \\
(\mathrm{mm})\end{array}$ & $B(D) / t$ & $\begin{array}{c}N_{0} \\
(\mathrm{kN})\end{array}$ & $\begin{array}{l}N_{\max } \\
(\mathrm{kN})\end{array}$ & $\frac{N_{\max }}{N_{0}}$ & $\frac{N_{s y}}{N_{0}}$ \\
\hline fiber reinforced square CFT & \multirow{2}{*}{100.0} & \multirow{2}{*}{47.4} & 1164 & 1232 & 0.98 & 0.25 \\
\hline un-reinforced square CFT & & & 1034 & 1050 & 1.02 & 0.28 \\
\hline un-reinforced circular CFT & 114.3 & 65.3 & 1034 & 1055 & 1.02 & 0.25 \\
\hline
\end{tabular}

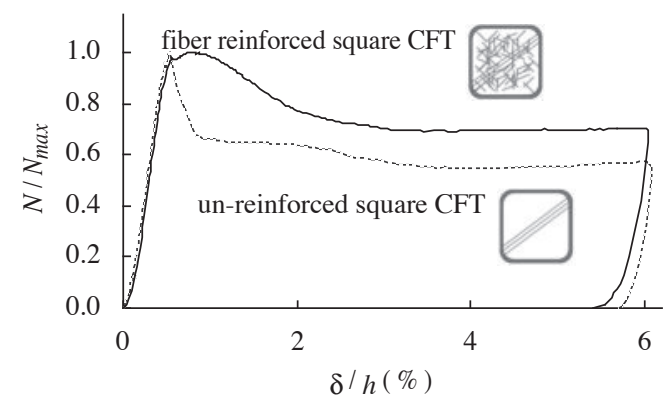

Fig.9 Effect of fiber reinforcement on $N-\delta$ relationship of square CFT short column

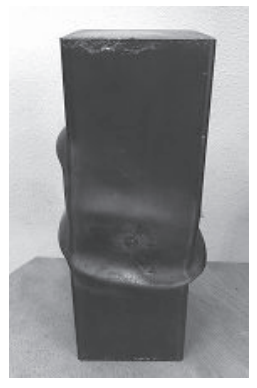

Photo.1 Failure mode of fiber reinforced square CFT

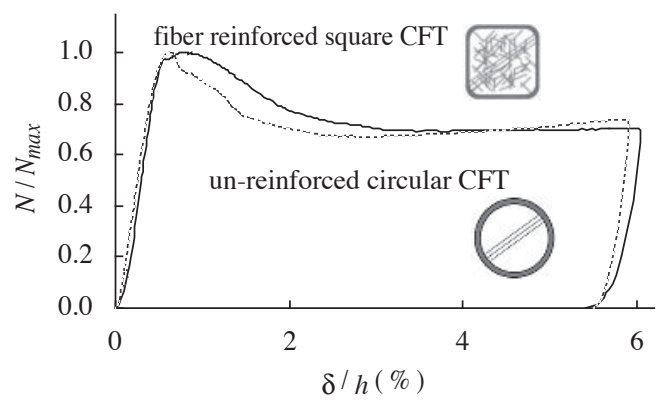

Fig.10 Comparison between fiber reinforced square CFT and un-reinforced circular CFT 
程度である注 7)。繊維補強角形 $\mathrm{CF}$ 短柱の最終破壊形状は, 無補強 のそれと比較し, 差異が認めらず, Photo. 1 に示寸ように通常の角形 $\mathrm{CFT}$ 短柱と同様に例えば, 5), 鋼管の螺旋状の局部座屈およびコンクリー 卜の局所的な破壊による鋼管板要素の膨張であった。

Fig.10 に, 繊維補強角形 CFT 短柱および無補強円形 CFT 短柱の最大 軸圧縮耐力で無次元化した圧縮而力と試験体高さに対寸る軸圧縮変 形の関係を併せて示す。

同図より, 繊維補強角形 CFT 短柱の最大圧縮耐力到達後の耐力低 下勾配および安定圧縮耐力は, それぞれ無補強円形 CFT 短柱のそれ とほとんど差異がないことが認められる。

\section{6. おわりに}

本論では, まず角形 CFT 短柱の安定圧縮耐力の評価式を提案した。 またその安定圧縮耐力を, 角形 CFT 柱の安定曲げモーメントの算定 に適用することが可能かを，既往の実験データを活用して検討した。 さらに, 高強度材料を使用した角形 $\mathrm{CFT}$ 柱の勒性改善を図ることを 目的として, 鋼繊維補強を施した角形 CFT 短柱の圧縮勒性についても, 実験的に検討した。これらより得られた主な結果を次に示す。

1）鋼管断面耐力比が同等の場合, 降伏応力度が高いほど, 安定圧 縮耐力は低下寸る。これは, 降伏応力度が高いほど一般化幅厚比 が高くなり，鋼管が負担する軸圧縮耐力が局部座屈の影響で低下 するためと考えられる。なお, 安定圧縮耐力は, 式 ( 2), ( 3 ) で表すことができる。

2）安定圧縮耐力, 平面保持の仮定などを用いた計算モデルで, 角 形 CFT 柱の安定曲げモーメントを算出した。その結果, 安定曲げ モーメントの計算值は, 実験值付近に存在し, かつ実験值と平行 であり，その傾向を表すことが判明した。ただし，高い軸力比およ び高い鋼管の降伏応力度では, 変数 $x_{n}$ が鋼管ウェブ $(B-2 t)$ 内にある 全ての場合において, 引張合力が圧縮合力より高く, 軸力が釣り合わ ないため, 安定曲げモーメントの解が得られない。これは, 計算モデ ルが，前掲のFig. 6に示寸ように, 鋼管の引張断面の全領域を降伏応 力度と仮定していることが原因である。よって, 高い軸力比および高 い降伏応力度では, 定数 $\beta$ を小さくする必要がある。しかし, 定数 $\beta$ と各種要因については不明であり, 今後の検討課題である。

3）鋼繊維補強による角形CFT 短柱の圧縮勒性の改善が認められた。 今後は, 安定曲げモーメントと軸方向変位例えば, 34) の関係, また それに及ぼす鋼繊維補強の影響について検討する予定である。

\section{謝辞}

本研究を進めるに当たり森野捷輔三重大学名誉教授, 福井伸之氏 ( 矢 作建設工業株式会社）に多大な御助力を頂きました。ここに記して感 謝致します。また, 研究成果を引用させていただいた多くの文献著者 およびこの分野で研究活躍された先駆者の方々に敬意と感謝の意を表 します。

\section{参考文献}

1）藤本利昭, 向井昭義, 西山功, 稲井栄一, 甲斐誠, 時野谷浩良, 馬塲武志, 福元敏之, 森浩二, 崎野健治, 森野捷輔: 高強度材料を用いたコンクリー 卜充てん鋼管柱の曲げせん断性状, 日本建築学会構造系論文集, 第 509 号, pp. 167-174, 1998. 7

2）徐培蓁, 河野昭彦 : 柱降伏を許容した CFT ラーメン構造の動的安定性につい
て，日本建築学会構造系論文集，No. 595，pp. 139-144，2005.9

3) 日本建築学会：コンクリート充填鋼管構造設計施工指針, 第 2 版, 2008. 10

4) Tsuiki, A., Kawaguchi, M., Fukao, H. and Morino, S. : Analysis of Cyclic Behavior of CFT Beam-Columns Failing in Local Buckling, Proceedings of the Fifth Pacific Structural Steel Conference, pp. 907-912, 1998. 10

5）山本貴正, 川口淳, 小池陝千朗, 森野捷輔 : コンクリート充填角形鋼管短 柱の軸圧縮特性に及ぼす断面寸法・形状の影響に関する実験的研究，日本 建築学会構造系論文集, No. 685 , pp. 597-605, 2013.3

6）林信之, 田内敏昭, 福元敏之, 佐伯俊夫 : 高強度材料を用いたコンクリー 卜充てん角形鋼管柱の軸圧縮性状, コンクリート工学年次論文報告集, Vol. 15, No. 2, pp. 977-982, 1993.6

7）中原浩之, 蜷川利彦, 崎野健治 : コンクリート充填鋼管柱の一定軸力下に おける繰返し曲げ性状, 日本建築学会構造系論文集, No. 568, pp. 139-146, 2003. 6

8）中原浩之, 稲井栄一, 崎野健治 : コンクリート充填角形鋼管短柱の中心圧 縮耐力, 構造工学論文集, Vol.44B, pp. 167-174, 1998. 3

9）中原浩之, 崎野健治, 稲井栄一：コンクリート充填角形鋼管柱の中心圧 縮性状のモデル化，コンクリート工学年次論文報告集，Vol.20, No.3, pp. 817-822, 1998.6

10）中原浩之，崎野健治：高強度材料を用いたコンクリート充填角形鋼管柱の 単調曲げ性状, 日本建築学会構造系論文集, No. 567, pp. 181-188, 2003.5

11）安部重孝, 石井修, 大島基義, 井ノ上一博, 沖本弘, 梅国章 : 部分溶込み 溶接組立角形鋼管柱の弾塑性性状に関寸る実験的研究 その 2 , 日本建築学 会大会学術講演梗概集, 構造 II, pp. 877-878, 1988. 10

12) Tomii, M., Yoshimura, K. and Morishita. : Experimental Studies on Concrete Filled Steel Tubular Stub Columns under Concentric Loading, International Colloquium on Stability of Structures under Static and Dynamic Loads, SSRC/ASCE, Washington, D. C., pp. $718-741, \quad 1977.3$

13）上遠野明夫，山口種美，斎藤豊，山口育夫，松谷輝夫，松村弘道：充填型 鋼管コンクリート柱に関する研究 その 1,2 , 日本建築学会大会学術講演 梗概集，構造 II，pp. 1613-1616，1989.10

14）田中清，狩野芳一，寺岡勝，佐々木聡：高強度コンクリートを用いた合成 短柱の中心圧縮性状, コンクリート工学年次論文報告集, Vol.12, No.2, pp. 83-88, 1990.6

15）吉富宏紀，森野捷輔，川口淳：コンクリートを充てんした角形鋼管の応力 一ひずみ関係に関する実験的研究, 日本建築学会大会学術講演梗概集, 構 造 II, pp. 1573-1574, 1994.9

16）小森淳, 吉田英敏, 荒木聡, 山中久幸, 小坂英之, 小田稳：充填鋼管二 ンクリート柱の力学的基本性質, 日本建築学会大会学術講演梗概集, 構造 II, pp. 1595-1596, 1994.9

17）渡辺英義, 竹崎真一, 成原弘之, 小林淳, 渡辺征晃, 中村敏治：コンクリー 卜充填鋼管柱の構造性能に関する研究 その 4 , 日本建築学会大会学術講演 梗概集，構造 III，pp. 773-774，1995.8

18）高巣幸二，松井千秋，津田恵吾，畑戸龍夫，多賀章，今村輝武，吉野茂， 宮木聡 : 圧縮力を受けるコンクリート充填角形鋼管の耐力と挙動, 日本建 築学会大会学術講演梗概集, 構造 III, pp. 779-780, 1995.8

19）藤本利昭, 向井昭義, 西山功, 稲井栄一, 甲斐誠, 田中義成, 時野谷浩良, 野口隆, 馬塲武志, 福本昇, 村田義行, 崎野健治, 森野捷輔: 高強度材料 を用いたコンクリート充てん鋼管短柱の軸圧縮特性, 日本建築学会構造系 論文集，第 498 号，pp. 161-168，1997.8

20）宮城聡，松井千秋，畑田竜夫：遠心成形コンクリート充填鋼管柱の耐力 · 変形性能, 日本建築学会構造系論文集, 第 500 号, pp. 105-112, 1997.10

21）松井千秋, 津田惠吾, 森武史 : 被覆形鋼管コンクリート柱材における鋼 管の幅厚比・径厚比の制限值, 日本建築学会構造系論文集, 第 503 号, pp. 157-163, 1998. 1

22）中原浩之, 崎野健治: 高強度コンクリートを用いたコンクリート充填角 形鋼管短柱の中心圧縮実験, 日本建築学会大会学術講演梗概集, 構造 I I, pp. 1131-1132, 1998.9

23) Yamamoto, T., Kawaguchi, J. and Morino, S. : Experimental Study of Scale Effects on the Compressive Behavior of Short Concrete-Filled Steel Tube Columns, Composite Construction in Steel and Concrete IV, ASCE, pp. 879-890, 2001.3-4.

24）高木潤一, 管田裕樹, 山口育雄, 諸菱亮太 : 長方形断面 CFT の中心圧縮 性状に関する実験的研究, 日本建築学会大会学術講演梗概集, 構造 I I, 
pp. 1103-1106, 2001. 7

25）北風野歩，菅野俊介，木村秀樹，片桐誠：超々高強度コンクリートを 用いた柱の圧縮特性に関する実験的研究，コンクリート工学年次論文集， Vol. 25, No. 2, pp. 847-852, 2003.7

26）雨宮篤，野口博：超高強度鉄筋コンクリート部材の有限要素解析プ ログラムの開発 その 1 , 日本建築学会大会学術講演梗概集, 構造 I I, pp. 639-640, 1990. 10

27）藤本利昭，向井昭義，西山功，野口隆，馬塲武志，崎野健治，森野捷輔： 高強度材料を用いたコンクリート充てん角形鋼管短柱の偏心圧縮実験, 日 本建築学会構造系論文集，第 501 号，pp. 173-180，1997.11

28）藤永隆, 三谷勲, 津田惠吾 : 角形 CFT 柱の繰返し挙動と単調挙動の比較, 構造工学論文集，Vol. 52B，pp. 395-399，2006.3

29) Kawaguchi, J. and Morino, S. : Experimental Study on Post-Local Buckling Behavior of CFT Beam-Columns under Cyclic Loading : Elasto-plastic behavior of square CFT beam-columns Part 1, 日本建築 学会構造系論文集, 第 540 号, pp. 141-148, 2001.2

30）渥美博，森野捷輔，川口淳：コンクリート充てん角形鋼管柱の局部座屈後 の耐力劣化性状に関する実験的研究 その 2 , 日本建築学会大会学術講演梗 概集，構造 II，pp. 1807-1088，1992.9

31）松井千秋，東野良之，尾崎功：高張力鋼を用いた中空及びコンクリート充 填角形鋼管柱の而力と変形能力に関寸る研究, 日本建築学会九州支部研究 報告集，第 33 号，pp. 357-360，1992. 3

32) 中村豪, 藤永隆, 三谷勲, 大谷恭弘: 角形 CFT 柱の復元力特性に関寸る研究, コンクリート工学論文集，Vol. 14，No. 2, pp. 31-41，2003.5

33) Amit, H. V., James, M. R. Richard, S. and Lu, L. W. : Seismic Behavior and Design of High-Strength Square Concrete-Filled Steel Tube Beam Columns, Journal of Structural Engineering, ASCE, pp. 169-179, 2004. 2

34）松井千秋, 津田惠吾, 山地雄二郎, 藤永隆: コンクリート充填角形鋼 管柱の構造性能と軸力制限值, 日本建築学会構造系論文集, 第 504 号, pp. 103-110, 1998.2

\section{注}

注 1）昨今, CFT 柱構造に超高張力鋼および超高強度コンクートが使用されつ つある。これら超高強度材料を用いた CFT 柱は，鋼管とコンクリートの各 強度の組み合わせによっては, 低勒性になることがある。また, 正方形 ( 以 下，角形）断面の CFT 柱の靭性は，円形のそれより低い傾向が認められて いる例えば, 1)

注 2）単調軸圧縮を受ける角形 CFT 短柱は, 耐力低下後にある程度変形が進む と，コンクリートの局所的な破壊による鋼管板要素の膨張で，鋼管断面が， 一様に拘束圧が作用する円形のように変形し，その後，再び耐力が上昇す ることがある。そこで, Table 1 の標本は, Fig.A1 (a) のように最小圧縮耐 力が認められる耐力 - 変形関係を示寸試験体としている。また, 耐力上昇 後，大変形時において，再び耐力低下寸る試験体は，Fig.A1(a) に示すよ
らに, 最初の谷を最小圧縮耐力としている。なお, Fig. A1 (b) に示すように, 緩やかに耐力が低下し続ける試験体は，最小圧縮耐力が認められないため， 標本としていない。これは，鋼管の幅厚比が小さく，コンクリートの耐力 再上昇が表れにくい，または再び耐力が上昇する前に圧縮試験を終了して いると考えられるためである。

注 3） Fig.2 に示すように, 安定圧縮耐力に対して, 降伏応力度が影響する。そ こで，抽出した標本を降伏応力度の大きさで 3 分割している。なお，その 内訳は, STKR400 クラス, STKR490 クラス, および左記以上の高張力鋼管で ある。

注 4） 中原ら 10) は，角形 CFT 短柱の一般化幅厚比およびコンクリートの圧縮 強度が高いほど, 等曲げモーメント - 無次元化曲率関係の勒性が低下寸る 実験結果を得ている。

注 5) 式 (4), ( 5 ) の定数 $S, r$ は, 下式で計算する。

$$
\begin{aligned}
& S=E_{s} \cdot \xi / \sigma_{y} \quad r=E_{c} \cdot \xi / \sigma_{B} \\
& \quad \xi=N_{\text {stab }} /\left(A_{s} \cdot E_{s}+A_{c} \cdot E_{c}\right) \\
& \quad \text { case } S>1.0: S=1.0, \quad r=\left(N_{\text {stab }}-A_{s} \cdot \sigma_{y}\right) /\left(A_{c} \cdot \sigma_{B}\right) \\
& \quad \text { case } r>1.0: r=1.0, \quad S=\left(N_{\text {stab }}-A_{c} \cdot \sigma_{B}\right) /\left(A_{s} \cdot \sigma_{y}\right)
\end{aligned}
$$

注 6) 安定曲げモーメントの解が得られる軸力比の最大值と鋼管断面耐力比の関係 に及ぼす鋼管の降伏応力度の影響について，その一例を Fig. A2 に示す。なお， 同一降伏応力度において, この関係に及ぼす幅厚比およびコンクリートの 圧縮強度の影響は，ほとんど認められない。

注 7）北風野らは ${ }^{25)}$, 鋼繊維混入率 $2 \%$ および鋼管断面力比 0.31 の角形 CF T 短柱の圧縮試験を実施し，最大圧縮耐力に対する安定圧縮耐力は，緎維補 強の有・無により，それぞれ 0.60 および 0.55 程度を得ている。

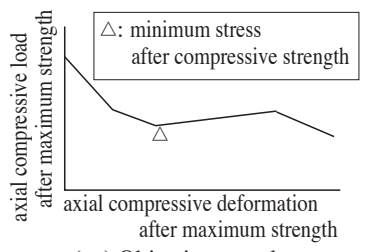

( a ) Objective sample

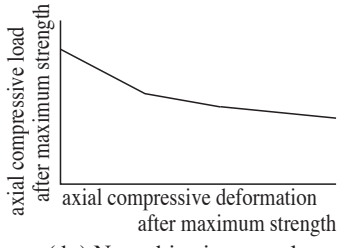

(b ) Non-objective sample
Fig.A1 Samples of shown in Table 1

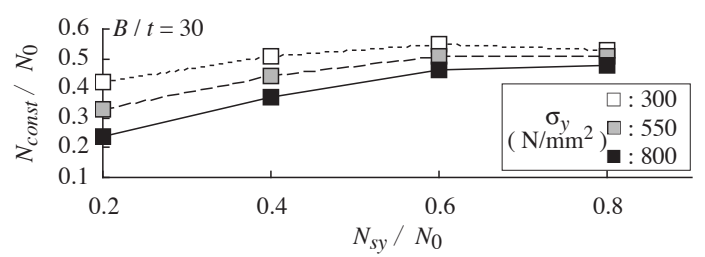

Fig.A2 Maximum of $N_{\text {const }} / N_{0}$ for Obtaining a Solution of $M_{\text {stab }}$ 


\title{
STABILIZED COMPRESSIVE STRENGTH UNDER PLASTIC DEFORMATION OF CONCRETE FILLED SQUARE STEEL TUBE SHORT COLUMNS
}

\author{
Takamasa YAMAMOTO*, Jun KAWAGUCHI** and Kazuo YAMADA*** \\ * Assoc. Prof., Dept. of Architecture, Toyota National College of Technology, Dr. Eng. \\ * Assoc. Prof., Graduate School of Engineering, Mie University, Dr. Eng. \\ *** Prof., Dept. of Architecture, Faculty of Engineering, Aichi Institute of Technology, Dr. Eng.
}

\section{Preface}

The authors estimated the deteriorated compressive strength of concrete filled square steel tube (square CFT) short columns after maximum strength attained, which is defined as the stabilized compressive strength $\left(N_{\text {stab }}\right)$. Next, the stabilized bending moment $\left(M_{\text {stab }}\right)$ of square CFT columns were calculated by use of $N_{\text {stab }}$. Compression tests of high strength square CFT short columns using steel fibered concrete (FR-CFT) were also carried out, in order to investigate improvement in the compressive ductility.

\section{Square CFT specimens investigated}

Square CFT specimens investigated are as follows: i) compressive load applied on both steel and concrete simultaneously, ii) no shear connector on the inner surface of steel tube, iii) no use of expandable admixture in concrete, iv) no void portion and no steel portion in concrete, v) no built-up box section, vi) within the limit of width-thickness ratio proposed by recommendations for design and construction of concrete filled steel tubular structures ${ }^{3)}$.

\section{Stabilized compressive strength}

The stabilized compressive strength $\left(N_{\text {stab }}\right)$ over $N_{0}$ tends to decrease as the yield strength of steel tube $\left(N_{s y}\right)$ over $N_{0}$ decreases; this becomes more obvious as the yield stress of steel tube increases (Fig.2). The reason is that the compressive load carried by higher-strength steel tube tends to decrease due to local buckling, because of larger generalized width-thickness ratio $\left[B / t\left(\sigma_{y} / E_{S}\right)^{0.5}\right.$. Its $N_{\text {stab }}$ can be calculated by using Eqs.(2) and (3). The standard deviation of calculated $N_{\text {stab }}$ over experimental ones is 0.101 (Fig.4).

\section{Stabilized bending moment}

The stabilized bending moment $\left(M_{\text {stab }}\right)$ was calculated using $N_{\text {stab }}$, based on assumed stress distributions in concrete and steel ${ }^{9)}$ under the stabilized stress state, and Bernouli-Euller's hypothesis (Fig.6). This calculation is based on ultimate bending moment expression ${ }^{9}$. This formulae are shown in Eqs.(4) and (5). The calculated $M_{\text {stab }}$ show good agreement with experimental maximum bending moment of final cycle (Fig.7). However it is not applicable to calculate the stabilized bending moment under higher axial load, because we assume that $\sigma_{y}$ is uniformly distributed along the tensile part of cross-section.

\section{Fiber Reinforced Square CFT Short Columns}

The square FR-CFT which contain 4.0\%(in volume) steel fiber was produced. The length of steel fiber is $40 \mathrm{~mm}$, and its diameter is 0.8 $\mathrm{mm}$. We carried out compressive test of its square FR-CFT, normal square CFT and circular CFT short columns. The axial compressive ductility of square FR-CFT short columns is higher than normal square CFT short columns (Fig.9), and it might be even higher than the ductility of un-reinforced circular CFT short columns (Fig.10).

\section{Conclusion}

The estimations of stabilized compressive strength $\left(N_{\text {stab }}\right)$ and stabilized bending moment $\left(M_{\text {stab }}\right)$ were proposed according to the intermission analysis. The proposed estimation showed the good agreement to the results of former experiments. The improvement in compressive ductility was also confirmed by tests of square FR-CFT short columns. 